\title{
The History of Makassar City: Physical and Administrative Development
}

\author{
Asmunandar* \\ Departemen of History Education \\ Faculty of Social Science \\ State University of Makassar \\ Makassar, Indonesia \\ asmunandar@unm.ac.id
}

\author{
Bahri \\ Departemen of History Education \\ Faculty of Social Science \\ Universitas Negeri Makassar \\ Makassar, Indonesia \\ bahri@unm.ac.id
}

\begin{abstract}
The development of Makassar City began from the conquest of Gowa's Kingdom by the VOC (Verenigde Oost Indische Compagnie) in 1667 which was marked by the Bungaya Treaty. One of the common grounds was to destroy all the fortresses owned by the Kingdom of Gowa, except Fort Ujungpandang. Speelman, leader of the VOC changed the name Ujungpandang Fortress to Fort Rotterdam and arranged settlements around it based on ethnicity. The research method used were library and field research. Literature research was obtained from Balai Pelestarian Peninggalan Purbakala (BP3) Makassar, Badan Perencanaan Pembangunan Daerah (Bappeda), Dinas Kebudayaan, Museum of Makassar and other literature review. The research indicates that history of the development of Makassar is inseparable from the role of colonialism that had taken place in Indonesia. During this period a number of physical buildings and supporting facilities were established like office buildings, educational facilities, residences, places of worship, hospitals, military buildings and public facilities. Makassar's physical development was followed by the administrative progress. Based on the Decentralization Act 1903 in conjunction with Algemeene Matregel van Bestuur 1903, Makassar was officially designated as an autonomous region or Makassar Gemeente which was effective since April 1, 1906, since then Makassar has developed as an autonomous government.
\end{abstract}

Keywords: History of Makassar City, Physical and Administrative Development

\section{INTRODUCTION}

Initially, Makassar City was the territory of the Makassar Kingdom, another name for the Kingdom of Gowa. The name Makassar was only known in the 14th century, which was listed in Desawarnana Pupuh XIV. It stated that the areas in the east of Java which were controlled by Majapahit in the mid-14th century included;

..... "Bantayan, Luwuk, Makassar, Buton, Banggawi, Salayar ....."[1].

Mattulada argues that the word Makassar in Desawarnana is a country which located in South Sulawesi. This opinion is reinforced by another name which is located on the Island of Sulawesi. Among them are Bantayan which is interpreted as Bantaeng, Luwuk refers to Luwu Regency (South Sulawesi Province), Buton refers to Buton in Southeast Sulawesi, Banggawi refers to Luwuk Banggai in Central Sulawesi and Salayar refers to Selayar Island in South Sulawesi[2].
During the reign of King Gowa IX Karaeng Tumapa'risi Kallonna (1512-1548) the Kingdom of Gowa was known for its political power and a large trading port, namely Gowa-Tallo. In Tome Pires' travel notes the Suma Oriental of Tome Pires in 1513, it was said that the Makassar people had traded with people from Malacca, Java, Borneo, Siam and all places between Pahang and Siam[3].

In 1528 the Kingdom formed a single power with the Tallo Kingdom which was to the north of Somba Opu Fortress, the capital of the Kingdom of Gowa. This alliance was called rua karaeng na se're ri ata which means "two rulers of one people"[4]. In the present context, Makassar City is located between the center of the Tallo Kingdom in the north and the center of the Kingdom of Gowa in the south.

The kingdom of Gowa then expanded its power in the South Sulawesi region. In its development, the ports . of the two twin kingdoms no longer showed clear dividing boundaries, thus traders and sailors who stopped at this port recognized it as a port under one management known as Makassar Port [5].

Several important things that were done by the king of Karaeng Tumapa'risi Kallonna,as such; changing the Makassar area from a confederation of communities to a unitary state of Gowa [6]. Compile a book of laws and methods of declaring war; The Kingdom of Gowa for the first time carried out substantial business with foreign traders, thus in the Kingdom of Gowa the word Syahbandar or port ruler from Persia was known. This fame was also strengthened by the Portuguese traveler named Antonio Paiva who transferred his ship to south from the port of Siang in 1544 to "the great Gowa where ships were better protected from the wind". This king was also the first to be visited by the Portuguese [7].

Since then, the Kingdom of Gowa has developed into a maritime empire. Its commercial fleet lies along the coast between the mouth of the Jenebarang River and the mouth of the Tallo River in the north which is called Maccini Sombala'. This port was known as the free port of the twin kingdoms of Gowa-Tallo (Makassar)[2].

The development of Makassar was closely related to the fall of Malacca to the Portuguese in 1511. The fall caused Malay traders to spread to other ports in search of a trading place that could be carried out safely and profitably. At first, Malay traders fled and settled in the Siang Kingdom, before finally moving to Makassar[6].

According to Reid, one of the factors that helped Gowa in the competition to attract the patronage of Malay 
merchants was the role of the Portuguese to Christianize the ruler of Siang, which resulted in Muslim Malay traders who had previously settled in the Siang Kingdom looking for other places. Another factor in the development of Makassar was the provision of "guaranteed freedom" for Malay merchants to settle in Makassar[7]. The guarantee was given because the Malay community was very experienced in international trade [6].

The 'open door' politics exercised by the Makassar Kingdom attracted not only Portuguese traders and sailors in Malacca and Malay but also traders who traded in East and Southeast Asia. The role of sailors and local traders such as Bugis, Makassar, Mandar, Selayar and Bajo, were very important because they carried out commercial shipping around Makassar, in Maluku which produces spices, and in Timor Sumba which produces sandalwood [8]. The Makassar Port then functioned as a meeting point for traders in carrying out important commodity exchange transactions at that time.

In the late 16 th to early 17 th centuries, Makassar had become the center of commerce of several European countries and China. During the reign of Tunipalangga Ulaweng Raja Gowa to X (1546-1565), Portuguese traders had increased trade relations with Makassar and established trade representatives.

The rapid development of the Makassar Kingdom in the spice trade with British traders and Portuguese traders caused hatred from the Verenigde Oost Indische Compagnie (VOC). The Dutch trading company wanted to control trade in Makassar and did not want traders from other countries to be in Makassar [8]. However, this desire received strong resistance from the King of Gowa to XIV Sultan Alauddin (1593-1639). As a defence anticipatory measure, Sultan Alauddin built Panakkukang, Garassi, Galesong and Ana Gowa Fortress.

On December 21, 1666 Cornelis Janszoon Speelman declared war to the Kingdom of Gowa. The war lasted until 18 November 1667, with the surrender of the Kingdom of Gowa to the Dutch. Sultan Hasanuddin as the King of Gowa was forced to enter into an agreement with the Dutch called the Bungaya Agreement. One of the common ground was to destroy all the fortresses of the Kingdom of Gowa except Ujung Pandang Fortress and hand over the fort and its villages and surroundings to the VOC[6].

Speelman, as the new ruler of Makassar, chose the Ujung Pandang Fort and the surrounding area as the center of the new settlement. The selection was based on natural conditions, strategic location, and was very suitable to be used as a port compared to other fortresses. This fort was renamed "Rotterdam". Fort Rotterdam was then used as an army headquarters and representative office for the VOC in the eastern archipelago. Speelman divided Makassar into four elements. First, the center of government which is in Fort Rotterdam. Inside the castle consisted of large stone walls, with division of spaces, blocks and gates. Around the fort became an exclusive Dutch settlement. VOC officials, government employees and soldiers generally resided in the fort and the surrounding area. Second, the settlement in the northeast of Fort Rotterdam grew and developed. This location is called "the merchant village with housing for foreigners and immigrants" or known as Negory
Vlaardingen. The inhabitants of this area were traders who came from Europe, Chinese and Christian natives. Third, which helped shape the structure and layout of settlements in the center of Makassar City was Kampong Melayu, a village located north of Vlaardingen. The name Kampong Melayu sticks from the tribe of its inhabitants, namely the Malays. The fourth, namely Kampong Beru or Kampung Baru, is located in the southern part of Fort Rotterdam, near the beach. In this area lived people from Asia as well as former Christian slaves who collaborated with the Dutch. They are known as Mardijkers [9].

\section{METHOD}

In this research, the method used is descriptive method. The main data sources for the physical development of the city are historical buildings and references related to the administrative development of Makassar City.

Technically, data collection is divided into two, namely library research and field research. For library research, the data used were the tangible and intangible, obtained from the literature of the Makassar Archaeological Heritage Conservation Center (BP3), the Regional Development Planning Agency (Bappeda), the internet, Makassar City Museum and other supporting written sources.

\section{RESULT AND DISCUSSION}

\section{A. Physical Development of Makassar City}

1. Late 17th to Early 18th Century

The history of Makassar City was begun from Fort Rotterdam, which was chosen by the Dutch as the center of government, trade and military. Fort Rotterdam underwent a major overhaul in 1673. Fort Rotterdam became the grandest and most beautiful building in the late 17 th century. Inside the fort there are several building units including a church, gunpowder warehouse, governor's residence, governor's office, city hall, the priest's residence, the office of the head of commerce, trade headquarters, military barracks, and warehouses (ship shed, coal warehouse and warehouse. for merchandise). Around the fort there is a perimeter ditch whose function is to cut off the connection between the inhabitants of the fort and the outside world and avoid the attacks of local residents, from the north, east and south.

The next development took place in the south of Fort Rotterdam which is called Kampung Baru. This section developed recently; therefore it is called Kampung Baru. Kampung Baru was inhabited by Asian people who worked together with the Christian company, or better known as Mardijkers or "Maradekayya", as the local community was called.

The population groupings in the late 17 th to early 18 th centuries were very clear. Egocentric ethnicity, nation or socio-economic interests form a mosaic, population groups and the spatial pattern of Makassar City [10]. Until now, this condition can be observed mainly from the names of the villages (toponyms) such as Kampung Melayu, Kampung Wajo, Kampung Baru and Maradekayya.

\section{Early 18th Century to Late 19th Century}

The structure of the city and important buildings in Makassar City around the early 19th century had facilities 
in the form of Koningsplein Field which is now called Karebosi Field. The southern part of the Koningsplein is used for infantry firing ranges.

On the north side of Koningsplein, there are three buildings that can reveal the characteristics of the Dutch government system, namely the executive and judicial elements, namely the Stadhuis building (City Hall), Gevangnis (prison) and Gerechtsplaats (court) [10].

In the late 19th century, the residence of the Dutch governor was built in 1885 and the Immanuel Protestant Church in 1885 in the eastern part of Fort Rotterdam. The Dutch government also built several important buildings including Pelamonia Hospital, Oliefabrik or an oil factory in the northern part of Koningsplein, Ysfabriek or an ice factory called Aurora and Gasfabriek (gas factory) to the east of Koningsplein [9].

In the next phase, Vlaardingen developed into Chinatown, the building is a mixture of Medieval and Chinese patterns with high fenced houses, without a front yard. Some evidence of his heritage was the Vihara Ibu Agung Bahari / Thian Ho Kong (1738). Other buildings included were the Nio Family Abu House (mid-18th century), Kwan Kong Temple (1810s), Ma Kiang Siang Temple (1860), the ancestral house of the Thoeng clan and the Thoeng Abadi's house (1898).

\section{Late 19th to Early 20th Century}

The structure of the city and important buildings in Makassar City around the early 19th century had facilities in the form of Koningsplein Field which is now called Karebosi Field. The southern part of the Koningsplein is used for infantry firing ranges.

On the north side of Koningsplein, there are three buildings that can reveal the characteristics of the Dutch government system, namely the executive and judicial elements, namely the Stadhuis building (City Hall), Gevangnis (prison) and Gerechtsplaats (court) [10].

In the late 19th century, the residence of the Dutch governor was built in 1885 and the Immanuel Protestant Church in 1885 in the eastern part of Fort Rotterdam. The Dutch government also built several important buildings including Pelamonia Hospital, Oliefabrik or an oil factory in the northern part of Koningsplein, Ysfabriek or an ice factory called Aurora and Gasfabriek (gas factory) to the east of Koningsplein [9].

In the next phase, Vlaardingen developed into Chinatown, the building is a mixture of Medieval and Chinese patterns with high fenced houses, without a front yard. Some evidence of his heritage was the Vihara Ibu Agung Bahari / Thian Ho Kong (1738). Other buildings included were the Nio Family Abu House (mid-18th century), Kwan Kong Temple (1810s), Ma Kiang Siang Temple (1860), the ancestral house of the Thoeng clan and the Thoeng Abadi's house (1898).

\section{Late 19th to Early 20th Century}

In this period the City of Makassar became an autonomous region under the name Gemeente Van Makassar on March 12, 1906 based on Stadblad No. 17 which was officially used on April 1, 1906. In order to strengthen the city's status, the City Hall or Gemeentehuis building was built in 1918. To the north of Fort Rotterdam, the Societeit de Harmonie building was built in 1896 adjacent to the CKC building (1910) .

In addition, Rathkamp dispensary was built (1920) and NV printing house. OGEM (1920s). Several school buildings have also been established, including the Eerste Europeesche Loger School (1910), Frobel School (1920), Arens School (1928), and MENALIA (1934). In addition, schools for indigenous people have also been built including OSVIA (1910), Kweekschool voor Inlandsche Schepelingen te Makassar (1915), Hollandsche Inlandsche School (1920), MULO (1927), Holland Chinese School (1907), Kwan Bun school (1920), Loen Djie Tong School (1930s), Eerste Ambonsche School, Tweede Ambonsche School (1906) and Katholike Sociale Bond (1940).

Still in this period, also built Raad van Justitie and Landraad (1915), a drinking water supply installation or Hamente Waterleiding (1920), Koninklijk Paketvaart Maatschaapij; Dutch Shipping Company and Javasche Bank building (1915), Mascapai Warehouse (1920), rice warehouse (1920), and Tjian Rijan \& Co. (1920) Post Cantoor (1925), Military Police Station (1935), Landrente (1940), Post en Telegraf Cantoor (1940) (Anonymous, 1992b)

In the early 20th century, the city of Makassar also built health facilities such as the Mental Hospital (Krankzinning Gestricht) (1920), Chinese Maternity Hospital (1938) and Stella Maris Hospital (1938) and Capitol Cinema (1950).

\section{B. Administrative Development of Makassar City}

Based on the Decentralization Law 1903 juncto Algemeene Matregel van Bestuur 1903, Makassar City was officially designated as an autonomous region or Gemeente Makassar which was declared effective on April 1, 1906. Since then Makassar has developed according to its function as the center of an autonomous government, which has the right to regulate and implement own governance.

The City Council or Gemeenteraad was formed to implement governance of Makassar City. The City Council is chaired by the Head of the Makassar Afdeling Regional Government (Het Hoofd van Het Plaatselijk Bestuur van de Afdeling Makassar) [11]. The City Council was still dominated by Dutch people in terms of organization and governance even though the population of Makassar City consists of local people.

In accordance with the ordinance contained in Staatsblad 1911 No. 614, the composition of the Makassar City Council plus two Dutch. In 1916 this council proposed that the post of mayor be held. This proposal was accepted by the Governor General in Jakarta, and in 1918 a Mayor (Burgemeester) Makassar was appointed who was also chairman of the Makassar City Council (Gemeenteraad).

In 1938, the status of Makassar City changed again from Gemeente to Kotapraja (Stadsgemeente). The consequence of this change in status was the expansion of the rights to regulate the city. When the Japanese army took control of Makassar City in 1942, Shi-Kay was formed, a kind of people's representative council. Its members were called Shi-Kay-Giin while the chairman was Shityo or mayor. This Japanese-made government ended 
until the dropping of the atomic bomb in Hiroshima by allied troops which made Japan surrender unconditionally.

After Japan left Makassar City, in 1946 the State of East Indonesia (NIT) was formed and Makassar City became the capital of the NIT. The role of Makassar City as the capital has caused politicians from various regions in eastern Indonesia as well as journalists from the Netherlands to arrive, adding to the cosmopolitan and multi-ethnicity of Makassar City. [12], [13]. But when the NIT was disbanded, the Makassar City area returned to the ranks of the Unitary State of the Republic of Indonesia (NKRI). After that the Makassar Municipal People's Representative Council was formed which was responsible for electing the first Makassar mayor, namely Achmad Dara Sjahruddin (1952-1956) [11].

In the period 1900's to the mid-20th century, when it became a standgemeente / municipal, Makassar was among other things the capital of Celebes Onderhorigheden (Sulawesi and its conquered areas), the capital of Groote Oost (Timur Besar), the capital of Residentie Zuid Celebes (Residency of Sulawesi South), then the capital of the State of East Indonesia.

An important change that occurred in connection with the structuring of the city of Makassar was the issuance of the Decree of the Resident of Celebes Selatan Number 427 dated June 3, 1947 which stipulated that all areas of the Makassar onderafdeeling, which were on the mainland, were designated as Makassar Municipality areas. Makassar Municipality consisted of Kampung Tallo, Kaluku Boddoa, Rappokalling, Rappojawa and part of Kalukuang. These five villages were formerly included in the Ujung Tanah District. [14]

In the era of the 1970s, the idea emerged that the Mayor of Makassar to expand the area of Makassar City as the capital of South Sulawesi Province. However, they did not receive the blessing of the three regents of neighbouring districts, namely Maros, Gowa and Pangkep. The reason is that the name Makassar is considered to characterize one tribe. However, this effort has received support from the military leadership, the governor and the former governor of South Sulawesi. Finally, the three regents expressed their willingness, on the condition that the name Makassar changed to Ujung Pandang.

The area of Ujung Pandang City has also expanded, from only about $25 \mathrm{~km}^{2}$ to $175 \mathrm{~km}^{2}$ as regulated in Government Regulation no. 51 of 1971 concerning Changes in the boundaries of the Makassar City area with Gowa, Maros and Pangkep within the Province of South Sulawesi.

For more than twenty years the name Ujung Pandang has been used, there have been attempts by various groups to try to return the name Ujung Pandang to Makassar, as well as to find a Makassar anniversary that matches the greatness of its name in the nation's history. This was manifested in the July 17, 1976 petition signed by three historical experts and humanists, namely, Andi Zainal Abidin Farid, Mattulada and H. D. Mangemba. The contents of the petition request that the name Ujung Pandang be returned to Makassar in order to uphold honesty, truth and historical straightness. One of the arguments was that the name Makassar was not limited to the name alone, but also included the language, ethnicity, culture and Kingdom of Makassar while Ujung Pandang was only a small part of Makassar City.

The central government then approved the issuance of Government Regulation no. 86 of 1999 dated October 13, 1999, which stipulates the return of the name of Ujung Pandang Municipality to Makassar City. Government Regulation No. 86 of 1999, signed by the President of the Republic of Indonesia B. J. Habibie.

\section{CONCLUSION}

Makassar City is a historical city that cannot be separated from the role of colonialism that has taken place in Indonesia. An important milestone in the formation of Makassar as a city was when the city moved from Fort Somba Opu to Fort Rotterdam which was designed by Speelman. Since then Makassar has experienced rapid development both in terms of physical buildings and government administration. A number of physical buildings and supporting facilities have been erected in the form of office buildings, educational facilities, and residential houses, places of worship, hospitals, military buildings and public facilities.

Meanwhile, in terms of government administration, it has also developed. Based on the Decentralization Law 1903 juncto Algemeene Matregel van Bestuur 1903, Makassar was officially designated as an autonomous region (gemeente) which took effect on April 1, 1906.Since then the City of Makassar has developed according to its function as the center of an autonomous government, which has the right to regulate and implement its own governance. In 1938, the status of Makassar City changed to Kotapraja (Stadsgemeente). The consequence is the expansion of city regulatory rights.

During the Japanese occupation in 1942, the Shi-Kay, a kind of House of Representatives, was formed. After Japan left Makassar City, in 1946 the State of East Indonesia (NIT) was formed and Makassar became the capital of the NIT. When the NIT was dissolved, the Makassar City area returned to the bosom of the Unitary State of the Republic of Indonesia. After that, the Makassar Municipal People's Representative Council was formed which was responsible for electing the first Makassar mayor, namely Achmad Dara Sjahruddin.

There has been a long history of Makassar until it was formed as a city like it is today. Its development was not only the physical development of buildings and infrastructure but also the development of administration until it becomes one of the metropolitan cities.

\section{ACKNOWLEDGMENT}

We would like to extend highly appreciation to Universitas Negeri Makassar, the Faculty of Social Sciences for sponsoring the writing of this article and to the research informants, especially the teachers, school principals, school committes, and parents who provided valuable information in this research.

\section{REFERENCES}

[1] S. Muljana, Nagarakretagama dan tafsir sejarahnya. Bhratara Karya Aksara, 1979. 
[2] Mattulada, Menyusuri jejak kehadiran Makassar dalam sejarah, 1510-1700. Ombak, 1991.

[3] T. Pires, Suma Oriental. Yogyakarta. Karya Tome Pires: Perajalanan Dari Laut Merah Ke Cina dan Buku ..., 2016.

[4] A. Rahim and R. Borahima, "Sejarah Kerajaan Tallo'," Ujung Pandang Pemerintah Drh., 1975.

[5] Asmunandar, "Membangun Identitas Masyarakat Melalui Kota Kuna Makassar," Universitas Gadjah Mada, 2009.

[6] L. Y. Andaya, The Heritage of Arung Palakka. Brill, 1981.

[7] A. J. S. Reid, S. S. S. Siregar, A. Wisesa, and R. Z. Leirissa, Sejarah modern awal Asia Tenggara: sebuah pemetaan. Lembaga Pendidikan, Penelitian, Penerangan Ekonomi dan Sosial (LP3ES), 2004.

[8] E. Poelinggomang, Makassar Abad XIX. Studi Tentang Kebijakan Maritim. Jakarta: Kepustakaan Indonesia Popular, 2002.

[9] Y. Sumalyo, "Ujung Pandang Perkembangan Kota dan Arsitektur Pada Akhir Abad 17 Hingga Awal Abad 20," Panggung Sej. Persembahan Kpd. Prof. Dr. Denys Lomb. Ec. Fr. d'extreme-Orient, Pus. Penelit. Arkeol. Nas., 1999.

[10] Anonim, "Pola Perkembangan Kota dan Arsitektur Ujung Pandang," 1992.

[11] Anonim, "Pedoman Kota Besar Makassar," Makassar, 1954.

[12] B. S. Harvey, Pemberontakan Kahar Muzakkar: dari tradisi ke DI/TII. Grafitipers, 1989.

[13] F. Colombijn, Kota lama, kota baru: sejarah kota-kota di Indonesia, sebelum dan setelah kemerdekaan. Ombak, 2005.

[14] Muchlis Paeni, Sejarah Sosial daerah Sulawesi Selatan : mobilitas sosial Kota Makasar, 1900-1950. Ujung Pandang: Departemen Pendidikan dan Kebudayaan, Direktorat Sejarah dan Nilai Tradisional, Proyek Inventarisasi dan Dokumentasi Sejarah Nasional 